Eurasian Journal of Business and Economics, 2016, 9 (17), 51-65.

\title{
Performance Evaluation of the Intermediary Channels of Life Insurance Industry in India
}

\author{
Sumninder Kaur BAWA*, Samiya CHATTHA ${ }^{* *}$
}

\begin{abstract}
The present study aims to canvass the performance of intermediary channels in Indian Life Insurance Industry viz. individual agents, corporate agents, bancassurance, brokers and direct selling. The conduct of performance has been deliberated in context of business premium collected and number of policies issued by various channels through Two-Way ANOVA. The data has been figured out over the period of seven years, i.e. from 2006- 07 to 2012-13. The findings demonstrate that in the context of premium as well as policy, there is difference in mean scores for various categories of channels, but no difference has been found with respect to time period. Besides the study also measures the augmentation in their performance, through compound annual growth rate (CAGR) by using the log linear regression model which reveals that individual agent is the foremost performing channel in terms of generating business. But sustaining efficacy of every channel has become one of the confronting issues for insurance domain.
\end{abstract}

Keywords: Intermediary Channels, CAGR, Life Insurance Industry, India, IRDA.

JEL Code Classification: G22, P17

UDC: $368.013(540)$

DOI: https://doi.org/10.17015/ejbe.2016.017.04

\footnotetext{
Associate Professor, University Business School, Guru Nanak Dev University, Amritsar, India. E-mail: skbawa gndu@yahoo.com

Research Scholar, University Business School, Guru Nanak Dev University, Amritsar India. E-mail: samiya_chattha@yahoo.com
}

Copyright (C, 2016 International Ataturk Alatoo University. 


\section{Introduction}

The performance of any entity depends how proficiently its intermediary network executes the business. In today's competitive scenario, the working of intermediate channels and maintaining a strong distribution network is an important constituent in sustaining growth, though it has become biggest confront (Krishnamurthy et.al, 2005: 104-105). But if the intermediaries are performing better, the success ultimately lies with the business. The scenario of Indian Insurance Industry reveals that it is one of the massive sectors of the economy and especially life insurance domain has set up the benchmark in its growth (Chaudhary \& Kiran, 2011:146-148) which is ultimately attained by the effectiveness of its distribution channels. According to (Kutty, 2010:26) and Desk (2013), since the nationalization of the Life Insurance Industry in India in year 1956 and opening up of the market by Insurance Regulatory Development Authority (IRDA) in year 2000, there were only individual agents working as a distribution channel with the industry (Vishwanathan, 2006: 20-21) but the last few years have witnessed the exceptional growth in the variety of distribution channels. According to Desk (2013), agents have been the biggest driving force for the Life Insurance Industry. Apart from the conventional ways of distributing an insurance policy, life insurers have been working with multiple and innovative distribution channels, namely corporate agents, bancassurance as corporate agents, brokers, direct selling and web aggregators for distributing its services to target customers (Govardhan, 2008: 7-8). Also, they are adopting a multi-channel distribution strategy to gain success and survive in a competitive environment.

The Figure 1 demonstrates that life insurance industry works only through its distribution channels to reach its customers. The working of intermediary channels thus becomes extremely important. They form an integral part in the success and survival of any organization (Rao, 2006: 12-13) and are considered an essential constituent of life insurance domain which serves as a connecting link between the insurers and customers (Etgar, 1976: 487-488). Intermediary channels are the chain of intermediaries through which goods or services reach to an end consumer.

An independent agent is a certified individual who sells insurance products on behalf of one insurance company (Cummins \& Doherty, 2006: 361). They receive commission from the insurance company on all policies sold. The only difference between individual and corporate agent is that latter is regarded as employees of the insurance companies who sell insurance products on behalf of company itself. But the channel does not gain popularity among insurers and customers in contrast to other channels. Bancassurance is a synergy of banks and insurance company whereby insurance products and services are sold by banking networks. According to Chevalier et.al (2005: 6-7), Anand and Murugaiah (2006: 74-76), Majumdar (2010: 58-60), Singaraju (2012: 28-30, Pani and Swain (2013: 11-13) stated that the channel is offering tremendous benefits to customers, insurers and bankers itself 
(Grover \& Bhalla, 2013: 64) and it was regarded as forthcoming and successful channel in terms of its growth and productivity.

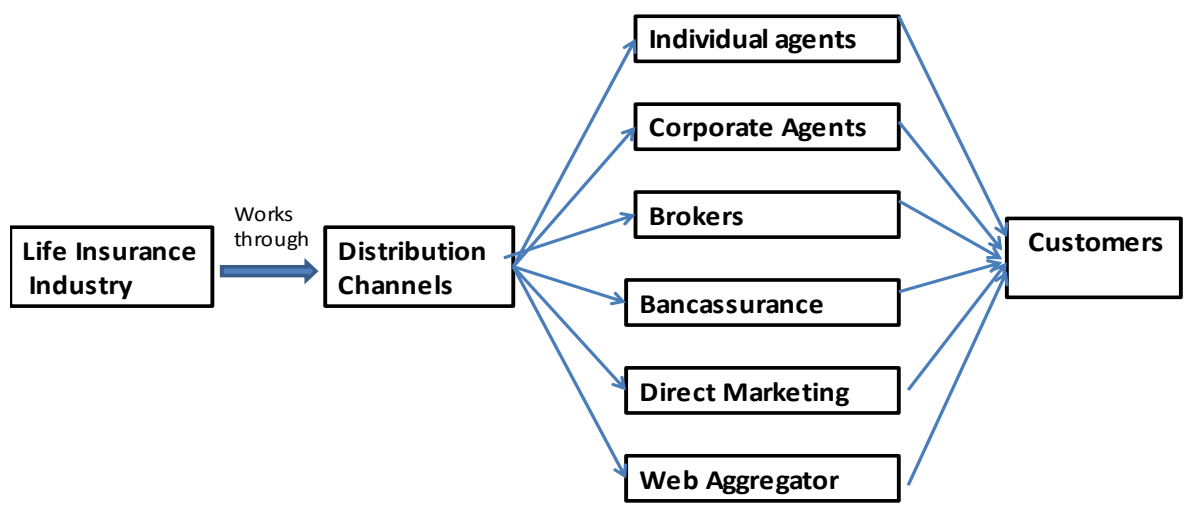

Figure 1. Conceptual Model

An insurance broker is an independent salesperson or the company who works for the customer, sells insurance products from multiple issuers. Radhakrishnan (2006:15), Rao (2006: 11-12) defined broker as the distribution channel which discovered the risk exposure needs of the consumers and plays a versatile role in serving them the best product according to their needs. Sethi (2008: 29) and Sithapathy (2008:21-22) observed that brokers enjoy a prominent place in the domain of insurance distribution as it presented a complete suite of insurance solutions. Direct selling is one of the flourished channels in the industry. Dumm and Hoyt (2002) stated that these are the companies who sell insurance products/policies directly to the consumer either through online or through phone.

For the survival and escalation of the industry in the changing environment and to remain dominating as before, the performance of intermediaries becomes really imperative to evaluate. So, the present paper focuses on assessing the growth and performance of intermediary channels in the Indian Life Insurance Industry. Including the introductory section which is highlighting the meaning and scope of distribution channels performing in life insurance industry, the rest of the paper is organized as follows: The next section presents the literature review followed by an examination of hypothesis and research methodology. The subsequent sections deal with empirical analysis of data and findings. The article concludes by providing discussions on the policy implications. 


\section{Review of Literature}

Lakshmikutty and Baskar (2006) highlighted the scenario of the Indian market that among various distribution channels, agents remained to be the primary channel of insurance. Both the public and private sector companies were finding their own ways to overcome the impediments and challenges faced by them from market perspectives. Viswanathan (2006), Gulati and Jain (2011) observed that distribution channels had been playing a vital role in the significant growth of an insurance industry. Prior opening of insurance industry to the private sector, it was linked with only tied agency channel. But after liberalization and privatization in year 2000, the emphasis revolved around creating alternative channels like brokers, bancassurance, direct marketing, telemarketing, net marketing and worksite marketing. Viswanathan (2006), Lakshmikutty and Baskar (2006) highlighted that the ultimate success of marketing of insurance channels depends on matching the right segment of customer with the right products at the right time with right distribution channel. Govardhan (2008) stated that an effective growth of business ultimately depends on the performance of various distribution channels. The study asserted that each distribution channel had been performing at its best in one way or another. Among the array of distribution channels, time tested channel had a long way to achieve success in emerging markets of insurance business. Majumdar (2010) made a conceptual analysis of different situation where the performance of distribution channels could be profitable. The study disclosed that although agents had brought maximum business to the life insurance industry through the business underwritten, but the bancassurance channel was regarded as an upcoming channel in terms of its growth and productivity. Parekh (2011), Bashir et.al (2013) concluded that in order to gain long term competitive advantages of the business, players were required to redesign their strategies and propose innovative and alternative channels to capture the potentials of untapped market and to sustain in the market. The insurers need to adopt the particular channel that offers better customer services and comprehend their needs. Rajeshwari and Christy (2012) examined the performance of individual agents in the Indian life insurance industry by studying a number of individual agents performing in the industry, individual business underwritten in terms of premium and policies and their spread over; in the few Indian states and union territories. The study showed that agents were abiding by the rules and regulations of IRDA. But competent advisory services of the agents and building vast customer base were considered the major aspects for enhancing insurance business. Baradhwaj (2013) enumerated that distribution channels were considered an essential constituent of the insurance sector and they had to follow certain guidelines to fulfill the regulations in their true spirit in order to sustain in the industry.

The review of above studies suggested that most of the research conducted is theoretical in nature focussing on impression in the course of role performed by various distribution channels. But there is a dearth in the empirical evidence for the 
concerned phenomena. There is hardly any empirical study conducted with respect to performance of intermediary channels in the Indian Life Insurance sector. In order to contribute to the closing of this gap, the present study made an attempt to analyze the pursuance of distribution channels in Insurance domain. The end result of the study would help to know that the momentous growth of insurance sector is owed to the performance of the distribution network.

\section{Empirical Analysis}

The empirical study has been demeaned to examine the performance of distribution channels in Indian Life Insurance Industry viz. individual agents, corporate agents, bancassurance, brokers and direct selling over the period of time with respect to business parameters. The performance has been measured on the basis of two variables, i.e. business premium collected and number of policies issued by all life insurance companies through various channels.

The study is secondary in nature and data have been collected from annual reports and handbook of Insurance Regulatory and Development Authority (IRDA) which has been analyzed over the period of seven years, i.e. from 2006- 07 to 2012-13. To scrutinize the results, Two-Way ANOVA and Post Hoc test has been applied. Since the data embraces some unique cases of interaction term and the model is not fit for interaction effect, so custom model of ANOVA has been used. The premium and policy variables are taken as dependent variable, whereas time period and channels are taken as independent variable. The assumptions of the technique viz. homogeneity of variance and normality by taking log of variables (premium and policy) have been considered. In order to examine the growth in various parameters, compound annual growth rate is calculated by applying regression model in its exponential form.

\subsection{Hypotheses Development}

According to Insurance Regulatory Development Authority, the insurance industry generates premium through the policies undertaken by their insurers, which ultimately helps in judging the performance (Pani \& Swain, 2013: 11-13) and thereby depend on the factors such as the complexity and terms of the contract, structure of distribution and method of payment. Also, the premium underwritten by insurers exhibit growth in the insurance industry, which has been spurred by product innovation, active sales and distribution channels. The insurers are particularly taking the lead of new channels which is evident from the increased percentage share of premium mobilized through various channels during time period of the study (Sethi, 2008: 29-31). So the study intends to estimate that:

$\mathrm{HO}_{1 a}$ : The amount of premium does not vary significantly with respect to the type of distribution channel.

$\mathrm{HO}_{2 a}$ : The issuance of policies does not vary significantly with respect to the type of distribution channel. 
In insurance industry the era after privatization, the demand for life insurance products has also increased which in turn led to the growth of in the number of distribution channels (Sethi, 2008:29-31). Hence credibility of insurers in imparting business also increases. But the obligations lie with respect to life insurers, which is indicated through a number of policies issued and the gross premium underwritten over the certain period of time (Kumari 2013:15). In lieu of the objectives, collection in the premium is through the number of policies issued, which is regarded a good measure of the business performance of the insurers. Moreover, the effectiveness of insurers and working of distribution channels are affected by their sustainability in the business which reflects augmentation in the business executed by them (Viswanathan, 2006: 20-21). So time period plays an imperative role in judging the performance of any parameter. Thus, the study proposed to considerate that:

$\mathrm{HO}_{1 b \text { : }}$ The amount of premium does not vary significantly with respect to time period.

$\mathrm{HO}_{2 b}$ : The issuance of policies does not vary significantly with respect to time period.

\subsection{Growth in the Performance}

The results are presented in two parts: First part reports the growth in the performance measured in terms of business contributed by various channels to the industry measured through CAGR. Second part is dedicated to the variation and comparison in the performance of channels during the study period which is reported through Two-Way ANOVA and Post Hoc test.

In order to determine the growth in the performance of distribution channels over the period of time, following CAGR model has been devised:

$\mathrm{Y}=\mathrm{abt}$

After computing its log

$\log Y=\log a+t \log b$

CAGR\% = antilog $(\log b-1) * 100$

Log $Y=$ Parameter whose CAGR is calculated

$\mathrm{a}=$ constant term

$\mathrm{t}=$ time period

$\log b=$ Regression coefficient

The graphs depict the growth in the business premium collected and number of policies issued by distribution channels over the period of seven years. The premium is the amount received by an insurance company through their intermediaries over a period of time on the basis of policies given to the policyholders (Christea \& Mitu, 2008: 62-63). The intermediaries serve as a bridge between policyholders (seeking to buy insurance policies) and insurance companies (seeking to sell those policies). 
Figure 4 reveals that brokers are showing highest growth of 23 per cent in premium variable, followed by banks with a growth rate of 18.06 per cent and direct selling with 14.11 per cent. This is because these channels are emerging in the industry, contributing very less in the initial years but show a gradual hike in their performance in current years (with reference to Figure 2) result in higher growth. No doubt the individual agent is considered the most efficient working channel contributing maximum business to the industry (better depicted by the data presented in Annexure) but still showing negative growth of 2.57 per cent. This is due to the reason that last few years had witnessed a steady performance of individual agents. It is one of the traditional working channels since the establishment of life insurance industry. Also, insurers as well as customers preferred to carry on their business with this particular channel only.

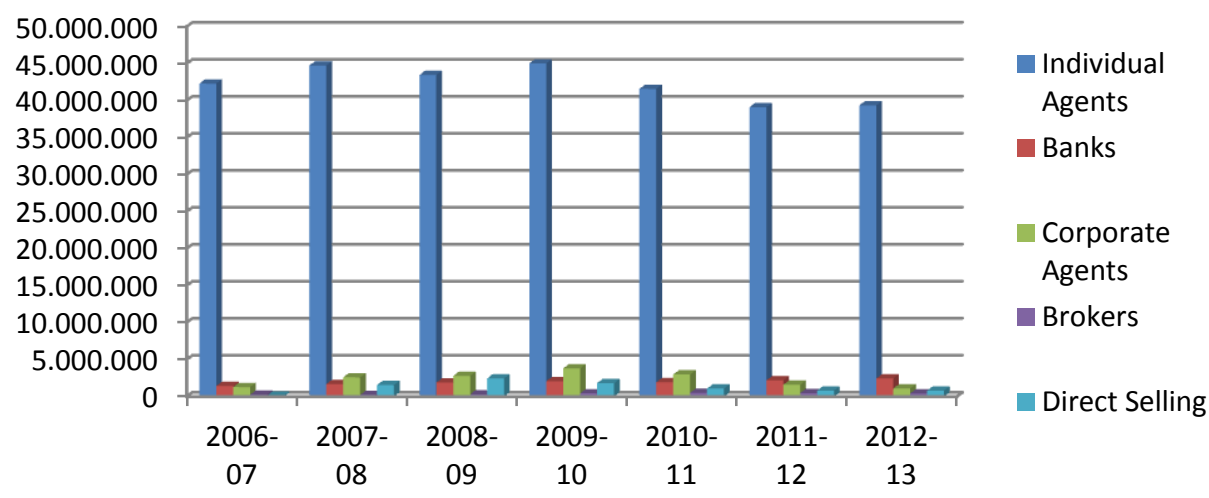

Figure 2: Performance of distribution channels in terms of premium

Source: IRDA Annual Reports

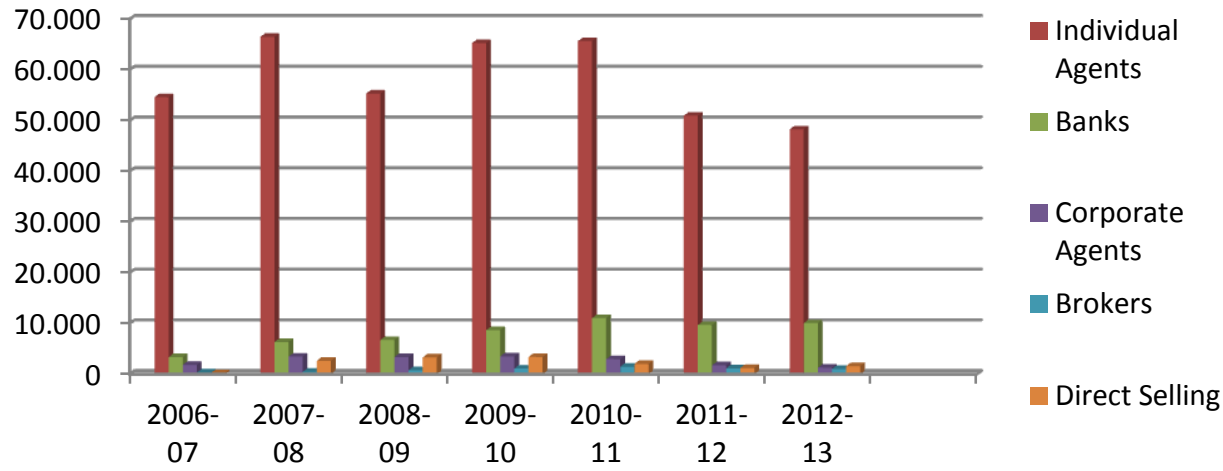

Figure 3: Performance of distribution channels in terms of policies Source: IRDA Annual Reports 
Figure 4 highlights that among various distribution channels, brokers are showing maximum growth of 13.31 per cent in policy variable also followed by direct selling and banks with growth of 11.96 per cent and 8 per cent respectively. With reference to Figure 3 the business contributed by these channels to the industry is very less but there is an augmentation in their respective performance over the time period resulting in excellent growth. An agent is one of the chief contributing channel of the industry (better depicted by the data given in Annexure), but even though showing negative growth rate of 1.88 per cent, as compared to other channels.

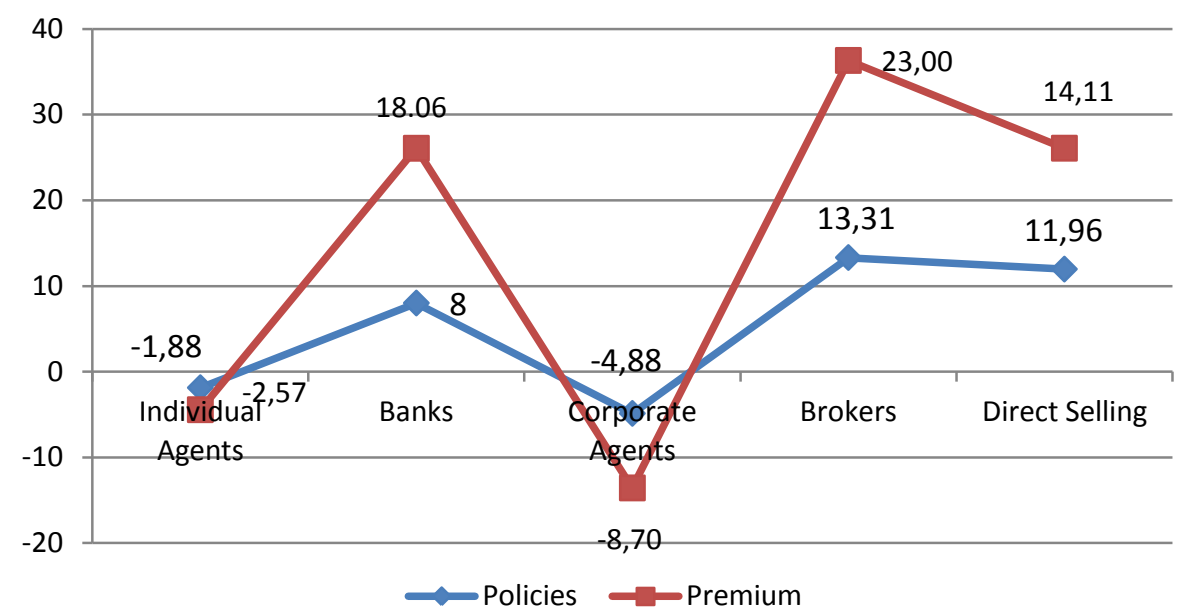

Figure 4: Growth in the performance of Distribution channels

Figures in percentage; Source: Author's Calculations.

The only reason is the sluggish increase in the performance over the period of time. But the channel maintained its reputation through its well known performance, as all the established life insurers are working with this channel.

\subsection{Two- Way ANOVA results and Hypothesis testing}

The above graphs depicted the business contribution of distribution channels in insurance industry. To have a deep insight of the performance of distribution channels, data have been evaluated insurer wise over the period of time. The analysis of Table 1 illustrates that there are differences in the performance across the channels.

To know whether these differences are statistically significant is tested using TwoWay ANOVA. The channel and time period are taken as independent (categorical) variables and premium is taken as dependent (continuous) variable. 
Performance Evaluation of the Intermediary Channels of Life Insurance Industry in India

Table1. Univariate Tests of Group Differences in Channel and Time Period

\begin{tabular}{llccccc}
\hline $\begin{array}{l}\text { Dependent } \\
\text { variable }\end{array}$ & Source & $\begin{array}{c}\text { Sum } \\
\text { of Squares }\end{array}$ & df & $\begin{array}{c}\text { Mean } \\
\text { Square }\end{array}$ & F & Sig. \\
\hline Premium & Corrected Model & 213.017 & 10 & 21.302 & 10.934 & $.000^{*}$ \\
& Intercept & 13034.211 & 1 & 13034.211 & 6690.075 & $.000^{*}$ \\
& Channel & 202.304 & 4 & 50.576 & 25.959 & $.000^{*}$ \\
& Time & 10.713 & 6 & 1.785 & .916 & .490 \\
\hline
\end{tabular}

R Squared $=.650$ (Adjusted R Squared $=.590$ )

Kolmogorov-Smirnov ${ }^{\prime} .200$ Shapiro-Wilk $=.116$

Levene's Test of Equality of Error Variances $=.113$

* Significant at 1 per cent level. Source: Author's Calculations.

The Levene's test is used to assess the tenability of the assumption of equal variances (homogeneity of variances). It looks at whether there is any significant differences between group variances (Field, 2005: 419-424) and so the non significant result i.e. $\mathrm{p}$ value $=0.113$ depicted in Table 1 indicated that assumption is met. The results of ANOVA tell that whether any of the independent variables have had an effect on the dependent variable. The $F$ ratio is highly significant (because of $p$ value less than 0.05) in case of channel. It reveals that premium (dependant variable) is found to be differing in its mean scores for the various categories of channels. But no difference is found in the mean scores for the various categories of time $(p=.490$, which is larger than 0.05$)$. In these respects $\mathrm{HO}_{1 \mathrm{a}}$ is rejected and $\mathrm{HO}_{1 \mathrm{~b}}$ is accepted (better depicted in Table 3 ) meaning thereby that differences across the channels in case of premium variable is significant.

The analysis of Table 2 depicts that channel and time taken are taken as independent (categorical) variable and policy is taken as dependent (continuous) variable.

Table 2. Univariate Tests for Group Differences in Channel and Time Period

\begin{tabular}{llccccc}
\hline $\begin{array}{l}\text { Dependent } \\
\text { Variable }\end{array}$ & Source & $\begin{array}{c}\text { Sum of } \\
\text { Squares }\end{array}$ & Df & $\begin{array}{c}\text { Mean } \\
\text { Square }\end{array}$ & F & Sig. \\
\hline Policy & Corrected Model & 198.709 & 10 & 19.871 & 9.986 & $.000^{*}$ \\
& Intercept & 3778.831 & 1 & 3778.831 & 1899.024 & $.000^{*}$ \\
& Channel & 191.343 & 4 & 47.836 & 24.039 & $.000^{*}$ \\
& Time & 7.366 & 6 & 1.228 & .617 & .716 \\
\hline
\end{tabular}

R Squared $=.629$ (Adjusted R Squared $=.566$ )

Kolmogorov-Smirnov $=.200$ Shapiro-Wilk $=.129$

Levene's Test of Equality of Error Variances $=.127$

* Significant at 1 per cent level. Source: Author's Calculations.

The non significance value of Levene Statistic ( $p$-value $=0.127$ which is greater than 0.05 ) assumes that assumption is met. Since the variances appear to be equal and variables are normally distributed (Kolmogorov-Smirnov ${ }^{3} .200$ ), we proceed with ANOVA. The results of two-way ANOVA indicate that policy (dependent variable) is found to be differing in its mean scores for the various categories of channels $(p<0.05)$ but no difference is found in the mean scores with respect to 
various categories of time. In this case $F$ ratio is not significant $(p=.716$, which is larger than .05). Follow-up univariate tests of group differences by examining the Fratio indicate that performance of channels differs in case of policy variable. Thus referring Table 3, hypotheses $\mathrm{HO}_{2 \mathrm{a}}$ is rejected and $\mathrm{HO}_{2 \mathrm{~b}}$ is accepted which denotes that in policy variable also, the performance of various channels differ significantly.

\section{Table 3. Summarizing the Hypotheses Results}

\begin{tabular}{lcclc}
\hline Hypothesis & Dependent Variable & Independent Variable & Sig. & Result \\
\hline $\mathrm{HO}_{1 \mathrm{a}}$ & Premium & Channel & $.000^{*}$ & Rejected \\
$\mathrm{HO}_{1 \mathrm{~b}}$ & & Time & .490 & Accepted \\
$\mathrm{HO}_{2 \mathrm{a}}$ & Policy & Channel & $.000^{*}$ & Rejected \\
$\mathrm{HO}_{2 \mathrm{~b}}$ & & Time & .716 & Accepted \\
\hline
\end{tabular}

Source: Author's Calculations.

\subsection{Post Hoc Analysis}

The analysis of two-way anova reports that between two independent variables (channels and time period), differences arises in the premium and policy for the various categories of channels. Field (2005: 339-341) suggests that to further find out which category of channel differ. There is a need to perform post hoc test.

Table 4 reports outcome of post hoc Tukey's HSD Test for pair-wise comparison of the channels that had significant univariate $\mathrm{F}$ values.

Table 4. Tukey's HSD Post Hoc Tests for Individual Group Differences

\begin{tabular}{|c|c|c|c|c|c|}
\hline \multicolumn{2}{|c|}{ Dependent (I) channel } & (J) channel & $\begin{array}{c}\text { Mean Difference } \\
(I-J)\end{array}$ & Std. Error & Sig. \\
\hline \multirow[t]{20}{*}{ Premium } & Individual & Bank & 2.854 & .527 & $.000^{*}$ \\
\hline & Agent & Corp Agent & 3.122 & .527 & $.000^{*}$ \\
\hline & & Broker & 5.350 & .527 & $.000^{*}$ \\
\hline & & Direct Selling & 2.798 & .527 & $.000^{*}$ \\
\hline & Bank & Ind. Agent & -2.854 & .527 & $.000^{*}$ \\
\hline & & Corp Agent & .267 & .527 & .614 \\
\hline & & Broker & 2.496 & .527 & $.000^{*}$ \\
\hline & & Direct Selling & -.056 & .525 & .915 \\
\hline & Corp Agent & Ind. Agent & -3.122 & .527 & $.000^{*}$ \\
\hline & & Bank & -.267 & .521 & 614 \\
\hline & & Broker & 2.228 & .527 & $.000^{*}$ \\
\hline & & Direct selling & -.323 & .527 & .542 \\
\hline & Broker & Ind. Agent & -5.350 & .527 & $.000^{*}$ \\
\hline & & Bank & -2.496 & .527 & $.000^{*}$ \\
\hline & & Corp Agent & -2.228 & .527 & $.000^{*}$ \\
\hline & & Direct Selling & -2.552 & .527 & $.000^{*}$ \\
\hline & Direct Selling & Ind. Agent & -2.798 & .527 & $.000^{*}$ \\
\hline & & Bank & .0563 & .524 & .915 \\
\hline & & Corp Agent & .323 & .525 & .542 \\
\hline & & Broker & 2.552 & .527 & $.000^{*}$ \\
\hline
\end{tabular}

* Significant at 1 per cent level. Minus sign indicates that group I has the lower value than group J Source: Author's Calculations. 
The test provides a significance value for each group of channel which is judged from the significance values. The only group that differed significantly is individual agent channel. However, performance of individual agent and broker is considerably unsurpassed than that of other channels. The mean difference (I-J) divulges that individual agent has considerable higher performance than other channels.

The Table 5 exemplifies the result of Tukey test, where each group of channel is compared to all other remaining groups. For each pair of groups; the difference between group means, standard error and significance level of that difference are displayed. The individual agent when compared to other groups reveals a significant difference (Sig. is less than .05) in all cases. Also values of mean differences (I-J) indicate that the only group that differed significantly is the individual agent since all values with respect to this group is positive. It specifies that performance of individual agent is incomparable and best as compared to other channels.

\section{Table 5. Tukey's HSD Post Hoc Tests for Individual Group Differences}

\begin{tabular}{|c|c|c|c|c|c|}
\hline \multirow{2}{*}{$\begin{array}{l}\text { Dependent } \\
\text { Variable }\end{array}$} & \multirow[b]{2}{*}{ (I) channel } & \multirow[b]{2}{*}{ (J) channel } & \multirow{2}{*}{$\begin{array}{c}\text { Mean Difference } \\
(I-J)\end{array}$} & \multirow[b]{2}{*}{ Std. Error } & \multirow[b]{2}{*}{ Sig. } \\
\hline & & & & & \\
\hline \multirow[t]{20}{*}{ Policy } & Individual & Bank & 2.318 & .533 & .001 \\
\hline & Agent & Corp. Agent & 3.645 & .533 & $.000^{\circ}$ \\
\hline & & Broker & 5.011 & .534 & $.000^{*}$ \\
\hline & & Direct Selling & 2.699 & .533 & $.000^{\circ}$ \\
\hline & Bank & Ind. Agent & -2.318 & .533 & $.001^{*}$ \\
\hline & & Corp Agent & 1.324 & .533 & .107 \\
\hline & & Broker & 2.693 & .531 & $.000^{*}$ \\
\hline & & Direct Selling & .381 & .533 & .952 \\
\hline & Corporate & Ind. Agent & -3.645 & .534 & $.000^{*}$ \\
\hline & Agent & Bank & -1.327 & .533 & .107 \\
\hline & & Broker & 1.366 & .533 & .091 \\
\hline & & Direct Selling & -.946 & .533 & .398 \\
\hline & Broker & Ind. Agent & -5.011 & .533 & $.000^{*}$ \\
\hline & & Bank & -2.693 & .533 & .000 \\
\hline & & Corp Agent & -1.366 & .533 & .091 \\
\hline & & Direct Selling & -2.312 & .533 & $.001^{*}$ \\
\hline & Direct & Ind Agent & -2.699 & .533 & $.000^{*}$ \\
\hline & Selling & Bank & -.381 & .533 & .952 \\
\hline & & Corp Agent & .946 & .533 & .398 \\
\hline & & Broker & 2.312 & .533 & $.001^{*}$ \\
\hline
\end{tabular}

* Significant at 1 per cent level. Minus sign indicates that group I has the lower value than group J Source: Author's Calculations.

\section{Conclusion and Policy Implications}

Managing distribution network is a key decision for a successful business. An exceptional system of distribution, results in efficient and productive performance 
of company (Chen \& Lai, 2010: 698-699). The present study intends to measure the performance of distribution channels (individual agents, corporate agents, bancassurance, brokers and direct marketing) in Indian Life Insurance Industry in context of business premium collected and number of policies issued. It also measures the growth in the performance of distribution channels.

The study demonstrates that each channel plays a valuable role in serving life insurance markets to function competently. It reveals that last few years have witnessed the growth in the performance of distribution channels, but individual agent is the leading one in terms of generating business. This channel is contributing maximum business to the insurance industry both in terms of premium income and policies issued in comparison to other numerous channels. Kutty (2010:32) and Rao (2004:11-13) highlighted that each distribution channel had its unique importance, but even then insurers rely basically on an individual agent channel in order to reach market. Tiwari and Yadav (2012: 142-145) and Sud (2012: 35-38) found that among various distribution channels, individual agent was considered the most preferred channel among the customers for buying a life insurance policy. The business performance of other channels, namely brokers, corporate agent and banks is very meager. But since these are emerging channels of industry, the trend of growth shows that these channels will become successful in coming years. Govardhan (2008: 7-10) asserted that each distribution channel was performing at its best in one way or another.

With respect to CAGR, direct selling channel is showing highest growth rate both in terms of premium and policies. According to Indian Insurance Statistics 2011-12, growth of the Indian life insurance industry is characterized by periods of higher CAGR of 31 per cent approximately in business premium between the year 2001 to 2010 which is attained through multiple channels (individual agents, corporate agents, bancaussurance, brokers, direct selling). The empirical evidence of the study shows that in the context of premium as well as policy variable, there found to be difference in the mean score for various categories of channels but no difference is found with respect to time period. It reveals that there is a lot of variation in the performance of the respective channels. According to Insurance Regulatory and Development Authority (IRDA), the speedy growth of the insurance industry, especially in life insurance segment has been brought by the individual agent channel which is considered as a link between the insured and the insurer. But there should be relaxation in the guidelines imposed by IRDA in order to spread out the growth and success of distribution channels. Srivastava et.al, (2012:98) reviewed that the emergence of the multi channel distribution network has developed the insurance sector, with their increased access and better services to customers. Coelho and Easingwood (2004:1-3) determine that in order to achieve expedition for further growth, insurers need to implement their strategies to shift from using a single channel sales approach towards adopting a multiple channel distribution strategy. Singh et.al, (2011: 56-61) and Bashir et.al, (2013) asserted that insurance companies need to modify their distribution strategies and to 
propose innovative and alternative channels to capture the potentials of untapped markets. A company's ability to offer an integrated multi-channel approach provides an undertaking for attaining customer satisfaction and profitable growth (Kasturi, 2006:157-163). Innovative and customized products can be offered to customers through multi channels. Also the insurance markets offer extent for better penetration and accessibility through diversified channels.

\section{References}

Anand, S, \& Murugaiah, V. (2006). Bancassurance: Indian context. SCMS Journal of Indian Management, 3(3), 73-81.

Bashir, I., Madhavaiah, C., \& Naik, J. (2013). Critical analysis of traditional and modern insurance distribution channels in India. Journal of the Insurance Institute of India,1(2). Retrieved from http://connection.ebscohost.com/c/articles/87005080/critical-analysistraditional-modern-insurance-distribution-channels-india

Baradhwaj, C L. (2013). Distribution compliance framework- vital hub of the wheel. IRDA Journal, 9 (9), 31-37.

Chaudhary, S., \& Kiran, P. (2011) Life Insurance Industry in India - Current Scenario. International Journal of Management \& Business Studies, 1(30), 146-150.

Chen, M. \& Lai, C. (2010). Distribution systems, loyalty and performance. International Journal of Retail and Distribution, 38(9), 698-718. http://dx.doi.org/10.1108/09590551011062448

Chevalier, M., Launay, C \& Mainguy, B. (2005). Analysis of bancassurance and its status around the world. Focus Scor Group Publication, 1-39. Retrieved from website:http://www.scor.com/images/stories/pdf/library/focus/Life_Focus_102005_EN.pdf

Christea, M., \& Mlitu, N E. (2008). Experience Studies on Determining Life Premium Insurance Ratings: Practical Approaches. Eurasian Journal of Business and Economics, 1 (1), 61-82.

Coelho, F., \& Easingwood, C. (2004). Multiple channel systems in services: pros, cons and $\begin{array}{llllll}\text { issues. The Service Industries Journal, } 24 & \text { (5), }\end{array}$ http://dx.doi.org/10.1080/0264206042000276810

Cummins, J., \& Doherty, N. (2006). The economics of insurance intermediaries. The Journal of Risk and Insurance, 73 (3), 359-396. http://dx.doi.org/10.1111/j.1539-6975.2006.00180.x

Desk, F. (2013). Distribution channels in life insurance. Retrieved from http://www.ehow.com/facts_6969877_difference-corporate-agent-broker insurance.html

Dumm, R. \& Hoyt, R. (2002). Insurance distribution channels: market in transition. Retrieved fromhttp://www1.iisonline.org/pdf/Insurance\%20Distribution\%20Channels\%20(JIR\%20sub mission). pdf

Etgar, M. (1976). Performance of insurance distributors. The Journal of Risk and Insurance, 43 (3), 487-499. http://dx.doi.org/10.2307/251915

Field, A. (2005). Discovering Statistics Using SPSS. London, Sage Publications.

Govardhan, N. (2008). Relevance of distribution channels. IRDA Journal, 6 (10), 7-10. 
Grover, N. \& Bhalla, G.S. (2013) Level of Awareness Regarding Bancassurance and Choice of Insurance Product among Bank Customers in India. Eurasian Journal of Business and Economics, 6 (12), 63-77.

Gulati, N.C., \& Jain, C. M. (2011). Comparative analysis of the performance of all the players of the Indian life insurance industry. VSRD International Journal of Business and Management Research, 1 (8), 561-569.

Kasturi, R. (2006). Performance management in insurance corporation. Spring, 5(1), 157-163.

Krishnamurthy, S., Mony, S, Jhaveri, N., Bakshi, S., Bhat R, Dixit, M., Maheshwari, S. (2005). Insurance Industry in India: structure, performance, and future challenges. Vikalpa, 30(3), 93-119.

Kumari, T.H (2013). Performance Evaluation of Indian Life Insurance Industry in Post Liberalization. International Journal of Social Sciences Arts and Humanities, 1(1), 7-14.

Kutty, S (2010). Indian life insurance - the millenial decade. Retrieved from

https://www.insuranceinstituteofindia.com/.../Journal.../The\%20Journal

Lakshmikutty, S., Baskar,S. (2006). Insurance Distribution in India: A Perspective. Retrieved from http://www.mib.com/kd/html/Insurance_Distribution_India.html\#

Majumdar, N. (2010). Increasing life insurance penetration in the next decade. Retrieved from website: https://www.insuranceinstituteofindia.com/.../Journal.../The\%20Journal.

Pani, L., \& Swain, S. (2013). Bancassurance and Indian banks. International Journal of Research and Development- A Management Review, 2 (1), 11-13.

Parekh, A. (2011). Current issues in Life Assurance. Retrieved from www.actuariesindia.org/CILA/CILA\%202011/Ashvin\%20Parekh.pdf

Radhakrishan, C. (2006). The broking profession -road ahead and challenges. IRDA Journal, 4 (1), 15-17.

Rajeshwari, K., \& Christy, F. (2012). Agents as the architects of life insurance industry- as assessment. Asian Journal of Research in Social Sciences and Humanities, 2 (3), 39-55.

Rao, G. (2006). Brokers in Indian and other markets- A comparative study. IRDA Journal, (1), 11-14.

Sethi, S. (2008). Role of intermediaries in Insurance. IRDA Journal 6(10), 29-31.

Singaraju, A. (2012). Need for pro active participation- bancassurance. IRDA journal, 10 (1), 28-30.

Singh, M.P., \& Chakraborty, A., G., R. (2011). Contemporary issues in marketing of life insurance services in India. International Journal of Multidisciplinary Research, 1 (7), 17-61.

Sithapathy, V. (2008). What has been and what will be - role of an insurance broker. IRDA Journal, 6(10), 21-22.

Srivastava, A., Tripathi, S., \& Kumar, A. (2012). Indian life insurance industry-the changing trends. Researchers World, 3(2), 93-98

Sud, R. (2012). Trailblazers in distribution: the agency channel. IRDA Journal, 10(1), 35-38.

Tiwari, A. \& Yadav, B. (2012). A customer survey and perception towards bancassurance with reference to life insurance industry. South Asian Journal of Marketing and Management Research, 2(2), 142-164.

Viswanathan, S. (2006). Role of distribution channels. IRDA Journal, 5 (1), 20-21. 
Performance Evaluation of the Intermediary Channels of Life Insurance Industry in India

\section{Annexure}

Table A.1. Individual New Business Performance of Life Insurers Channel Wise

\begin{tabular}{|l|c|c|c|c|c|c|c|}
\hline & \multicolumn{7}{|c|}{ Number of Policies Issued } \\
\cline { 2 - 8 } & $2006-07$ & $2007-08$ & $2008-09$ & $2009-10$ & $2010-11$ & $2011-12$ & $2012-13$ \\
\hline $\begin{array}{l}\text { Individual } \\
\text { Agents }\end{array}$ & 42301907 & 44752611 & 43460589 & 45036904 & 41581811 & 39103141 & 39370820 \\
\hline Banks & 1426919 & 1693610 & 1896457 & 2084543 & 1936562 & 2180018 & 2452767 \\
\hline $\begin{array}{l}\text { Corporate } \\
\text { Agents }\end{array}$ & 1284785 & 2599723 & 2798776 & 3819790 & 2988481 & 1588650 & 1093960 \\
\hline Brokers & 259177 & 227403 & 306277 & 439396 & 511388 & 476054 & 427151 \\
\hline $\begin{array}{l}\text { Direct } \\
\text { Selling }\end{array}$ & 139077 & 1573849 & 2442772 & 1814558 & 1088426 & 812478 & 809926 \\
\hline
\end{tabular}

\begin{tabular}{|l|c|c|c|c|c|c|c|}
\hline & \multicolumn{7}{|c|}{ Amount of Premium (in Crores) } \\
\cline { 2 - 8 } & $2006-07$ & $2007-08$ & $2008-09$ & $2009-10$ & $2010-11$ & $2011-12$ & $2012-13$ \\
\hline $\begin{array}{l}\text { Individual } \\
\text { Agents }\end{array}$ & 54605.3 & 66515.43 & 55327.54 & 65289.25 & 65665.52 & 50972.32 & 48257.36 \\
\hline Banks & 3363.17 & 6329.22 & 6737.38 & 8688.68 & 11062.63 & 9692.9 & 10072.96 \\
\hline $\begin{array}{l}\text { Corporate } \\
\text { Agents }\end{array}$ & 1825.89 & 3461.89 & 3380.54 & 3510.76 & 2957.75 & 1749.78 & 1288.68 \\
\hline Brokers & 331.63 & 473.73 & 773.62 & 1128.5 & 1471.8 & 1134.64 & 1033.15 \\
\hline $\begin{array}{l}\text { Direct } \\
\text { Selling }\end{array}$ & 235.33 & 2642.71 & 3310.33 & 3389.85 & 2016.32 & 1222.61 & 1588.71 \\
\hline
\end{tabular}

Source: Annual Reports of IRDA 